\title{
Późnogotycka Madonna Apokaliptyczna z ołtarza głównego kościoła Bernardynów w Krakowie - dzieło malarza Franciszka z Węgier
}

$\mathrm{W}$ 2012 r. do Pracowni Konserwacji Malowideł na Drewnie Wydziału Konserwacji i Restauracji Dzieł Sztuki krakowskiej Akademii Sztuk Pięknych trafił obraz tablicowy przedstawiający Marię z Dzieciątkiem, pochodzący z klasztoru Bernardynów w Alwerni (il. 1-4). Dziełem tym zająłem się w ramach mojej pracy magisterskiej, którą w 2015 r. obroniłem na tymże wydziale. W trakcie pisania udało mi się ustalić, że obraz znajdował się pierwotnie w ołtarzu głównym kościoła Bernardynów w Krakowie, a jego autorem był Franciszek z Węgier, bernardyński malarz zmarły w krakowskim klasztorze pomiędzy 1487 a 1491 r. Dzieło to nie zajmowało do tej pory uwagi badaczy, a stan badań ogranicza się do kilku zdawkowych informacji w Katalogu Zabytków Sztuki w Polsce 1 i karcie ewidencyjnej obiektu² oraz pewnych wiadomości o jego historii podanych przez monografistów dziejów konwentu w Alwernii - Hieronima Wyczawskiego ${ }^{3}$ i Dominika Knapika ${ }^{4}$.

W przeciwieństwie do samego dzieła osoba jego twórcy pojawia się w literaturze wielokrotnie. Wspomina o nim Wilhelm Gąsiorowski w publikacji z 1860 r., w której podaje ustaloną na podstawie źródeł archiwalnych datę śmierci malarza (6 marca 1487) i uznaje go za autora obrazów z przedstawieniami Wieczerzy Pańskiej, Ukrzyżowania i Upadku Chrystusa znajdujących się w Krakowie oraz Ukrzyżowania w kościele w Kalwarii ${ }^{5}$. Jest to jednak błędna informacja, a wykorzystany przez autora dokument można uznać za tożsamy

\footnotetext{
${ }^{1}$ Katalog Zabytków Sztuki w Polsce, t. 1: Województwo krakowskie, red. Jerzy SZABLOWSKI, z. 4: Powiat chrzanowski, oprac. Jerzy SZABLOWSKI, Warszawa 1952, s. 97-98.

${ }^{2}$ Karta ewidencyjna obiektu, udostępniona przez Archiwum Narodowego Instytutu Dziedzictwa.

${ }^{3}$ Hieronim Eugeniusz WYCZAWSKI, Alwernia. Dzieje klasztoru oo. Bernardynów, Kraków 1957, s. 19-20, 31, 36-37.

${ }^{4}$ Dominik KNAPIK, Bernardyni alwernijscy. Dzieje klasztoru oo. Bernardynów w Alwerni, Kraków 2014, s. 35, 36, 44, 118, 120, 297.

${ }^{5}$ Wilhelm GĄSIOROWSKI, Cechy krakowskie. Ich dzieje, ordynacye, listy swobody, zwyczaje i t. p., Kraków 1860, s. 34-37. Autor zaczerpnął informacje z, jak sam to określił, Księgi zmarlych braci z klasztoru bernardynów w Krakowie. Na jej podstawie podał w wątpliwość informacje zawarte w opublikowanym dziesięć lat wcześniej Słowniku malarzów polskich Edwarda Rastawieckiego, który dzieła o takich tytułach przypisał Franciszkowi Lekszyckiemu; zob. Edward RASTAWIECKI, Stownik malarzów polskich, tudzież obcych w Polsce osiadtych lub czasowo w niej przebywajacych, Warszawa 1850, s. 265-268.
} 
z jedną z kopii tzw. Kalendarza Tymoteusza Kaffki ${ }^{6}$, będącą źródłem, w którym Franciszkowi z Węgier omyłkowo przypisano dzieła Franciszka Lekszyckiego ${ }^{7}$.

W późniejszym czasie o Franciszku z Węgier wspominali również Norbert Golichowski $^{8}$, Kamil Kantak ${ }^{9}$, Jerzy Szablowski ${ }^{10}$ i Michał Walicki ${ }^{11}$, a nieco dokładniej zajął się nim Tadeusz Dobrowolski, który uznał, że artysta ów, czynny wkrótce po 1450 r., może być autorem iluminacji w jednym z kodeksów powstałych w krakowskim konwencie Bernardynów ${ }^{12}$. Pierwszym, który bardziej szczegółowo zainteresował się postacią Franciszka z Węgier, był Władysław Terlecki. Planował on poświęcić artyście osobne opracowanie, niestety zmarł w 1958 r. nie zrealizowawszy tego zamiaru ${ }^{13}$. Pozostawił jednak znaczną część opracowanego tekstu w formie maszynopisu. Badacz ten utożsamił Franciszka z Węgier z osobą Jakuba z Sącza ${ }^{14}$ i uznając obu za jednego malarza przypisał mu szereg dzieł z terenów Małopolski i Spisza, datowanych na przełom 1. i 2. połowy XV w. ${ }^{15}$

Franciszek z Węgier ma także biogram w Słowniku artystów polskich i obcych w Polsce działajacych autorstwa Marii Łodyńskiej-Kosińskiej, która powtórzyła m.in. za Gąsiorowskim błędne informacje o autorstwie wspomnianych wyżej obrazów ${ }^{16}$. Malarz ten był ponadto wymieniony w artykule Marii Otto-Michałowskiej i Marii Luisy Pezzi-Ascani z roku 1975, które przypisały mu dwa przedstawienia Opłakiwania - z Czarnego Potoka i Żywca, wiązane ze środowiskiem małopolskim i datowane na ok. 1450 r. Uznały również, że pozostawał pod wpływem węgierskiego malarza, przybyłego do Krakowa

\footnotetext{
${ }^{6}$ Kalendarz spisany w 1752 r. przez Tymoteusza Kaffkę, ze wspominkami zmarłych w Polsce zakonników bernardyńskich. Oryginał nie istnieje, ale zachowało się kilka jego kopii: Archiwum Prowincji oo. Bernardynów w Krakowie (dalej: APBK), Archiwum Klasztoru w Opatowie, VII-2; APBK, Archiwum Klasztoru w Kalwarii Zebrzydowskiej, IVb-7; APBK, Archiwum Klasztoru w Radomiu, XI-1; APBK, Archiwum Klasztoru w Krakowie (dalej: AKK), I-b-21; APBK, AKK, I-b-22. Zob. Wiesław MURAWIEC, „Kaffka Tymoteusz Emanuel”, [w:] Stownik polskich pisarzy franciszkańskich (bernardyni i franciszkanie ślascy, franciszkanie konwentualni, klaryski oraz zgromadzenia III reguły), red. Hieronim Eugeniusz WYCZAWSKI, Warszawa 1981, s. 203-204.

${ }^{7}$ Najprawdopodobniej była to XIX-wieczna kopia, w której pojawia się notka brzmiąca identycznie, jak zacytowana przez Gąsiorowskiego; zob. APBK, AKK, I-b-22, s. 69.

${ }^{8}$ Norbert GOLICHOWSKI, Przed nowq epokq. Materyały do historyi oo. Bernardynów w Polsce, Kraków 1899, s. 273.

${ }^{9}$ Kamil KANTAK, Bernardyni polscy, t. 1, Lwów 1933, s. 44.

10 Jerzy SZABLOWSKI, „Architektura krakowskiego kościoła bernardynów”, [w:] Kamil KANTAK, Jerzy SZABLOWSKI, Jerzy ŻARNECKI, Kościól i klasztor OO. Bernardynów w Krakowie, Kraków 1938, s. 75 (Biblioteka Krakowska, t. 96).

${ }^{11}$ Michał WALICKI, Malarstwo polskie XV wieku, Warszawa 1938, s. 4-6; id., „Renesansowy tryptyk z Warty”, Studia Muzealne, 1957, t. 2, s. 105; id., Złoty widnokrag, Warszawa 1965, s. 22, 156. Autor jako pierwszy uznał, że Franciszek z Węgier zmarł między latami 1487 a 1491, nie zaś jak jego poprzednicy w $1487 \mathrm{r}$.

12 Tadeusz DOBROWOLSKI, Życie, twórczość $i$ znaczenie społeczne artystów polskich $i$ w Polsce pracujacych w okresie późnego gotyku (1440-1520), Wrocław-Warszawa-Kraków 1965, s. 82. Dobrowolski pisał o kodeksie, którego miniatury miałyby być wzorowane na ołtarzu z Ptaszkowej. Chodzi tutaj o tzw. Graduale de tempore - graduał bernardyński wykonany w Krakowie wkrótce po 1453 r.; zob. Barbara MIODOŃSKA, Małopolskie malarstwo ksiażkowe, Warszawa 1993, s. 148-149.

${ }^{13}$ Ludwik GRAJEWSKI, „Władysław Terlecki 1891-1958”, Biuletyn Historii Sztuki, XXI:1959, nr 2, s. 238-239.

${ }^{14}$ Władysław TERLECKI, Franciszek Wegrzyn, maszynopis, Warszawa, Instytut Sztuki PAN, Zbiory Specjalne Biblioteki IS PAN, nr inw. 1333, s. 37-39.

${ }^{15}$ Były to kolejno: ołtarz z Łopusznej, który uznał za pierwszy ołtarz główny kościoła Bernardynów w Krakowie, ołtarze św. Andrzeja i nieistniejący obecnie ołtarz św. Idziego z kościoła św. Idziego w Bardejowie, obraz Trzy Święte Dziewice z Sandomierza, skrzydła z Chełma, ołtarze z Podgrodzia, Kamionki Wielkiej, Niedzicy, Przydonicy, Grybowa, Biecza, Ptaszkowej i z Maciejowic na Spiszu; zob. TERLECKI, op. cit., s. 11-101.

${ }^{16}$ Maria ŁODYŃSKA-KOSIŃSKA, „Franciszek z Węgier”, [w:] Stownik artystów polskich i obcych w Polsce działajacych, t. 2, Wrocław-Warszawa-Kraków-Gdańsk 1975, s. 240.
} 


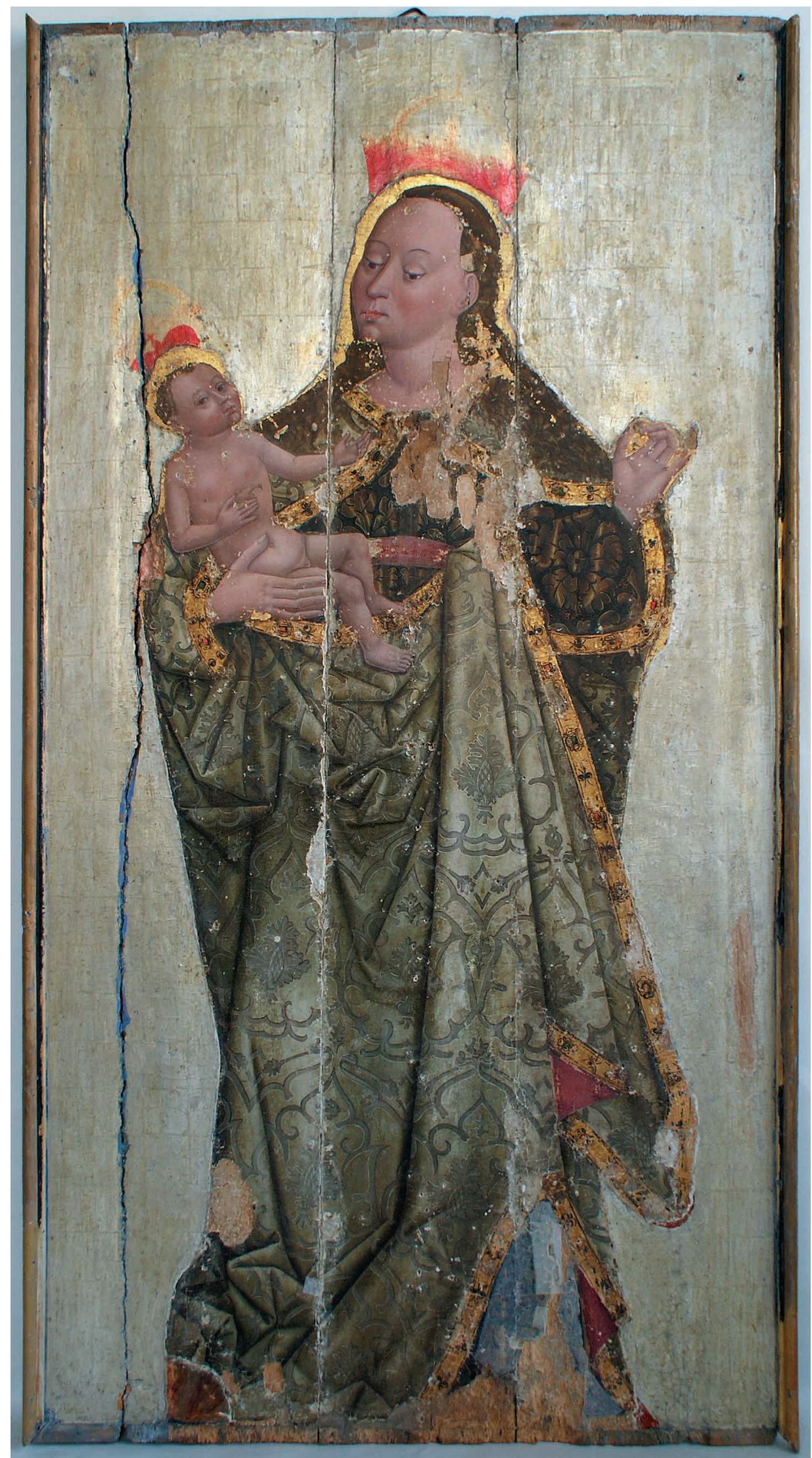

1. Franciszek z Węgier, Madonna z Alwerni - stan po zdjęciu przemalowań, tempera na desce, przed 1491, klasztor oo. Bernardynów w Alwerni. Fot. B. Zarębski 


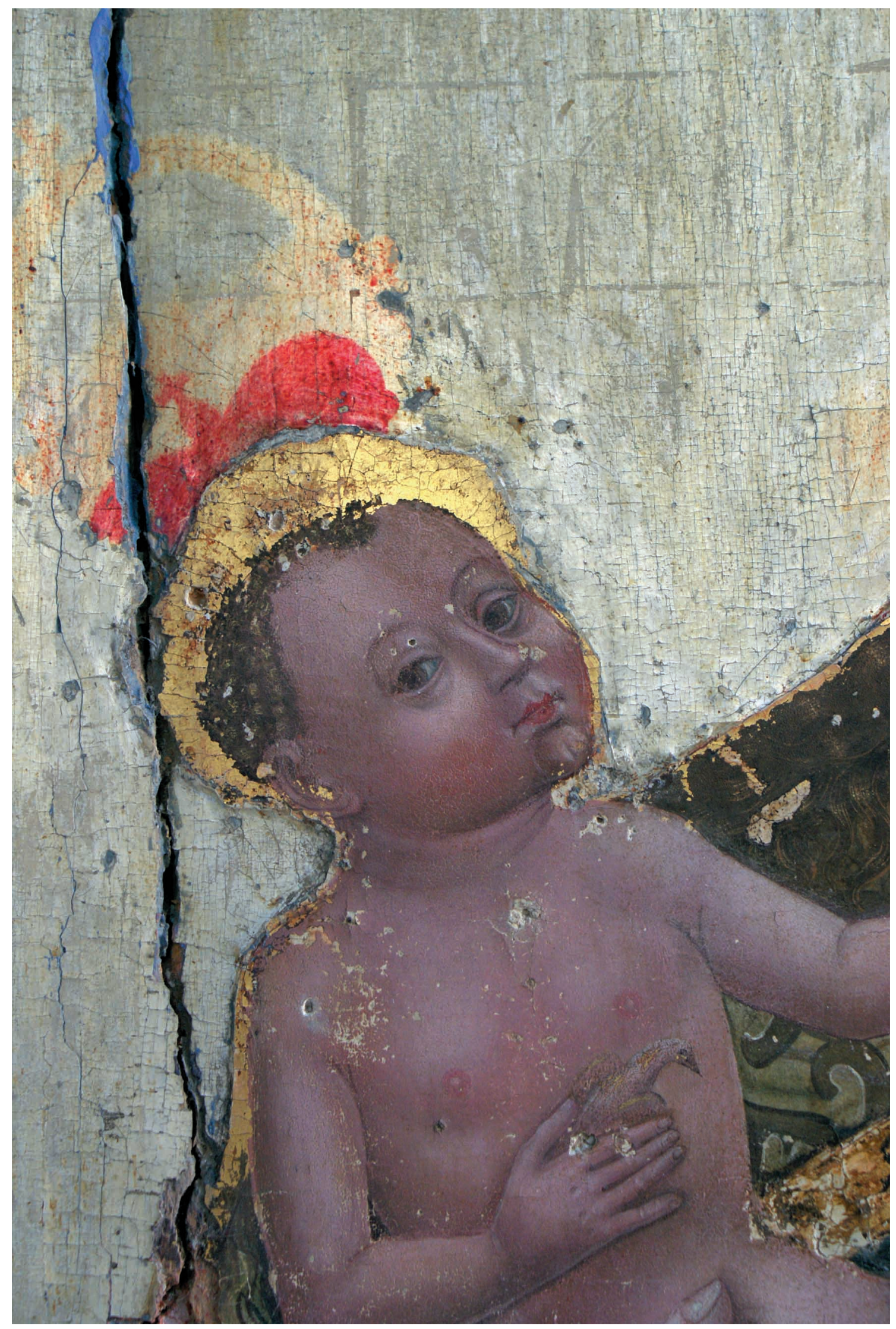

2. Franciszek z Wegier, Madonna z Alwerni - zbliżenie na twarz Dzieciatka, tempera na desce, przed 1491, klasztor oo. Bernardynów w Alwerni. Fot. B. Zarębski 


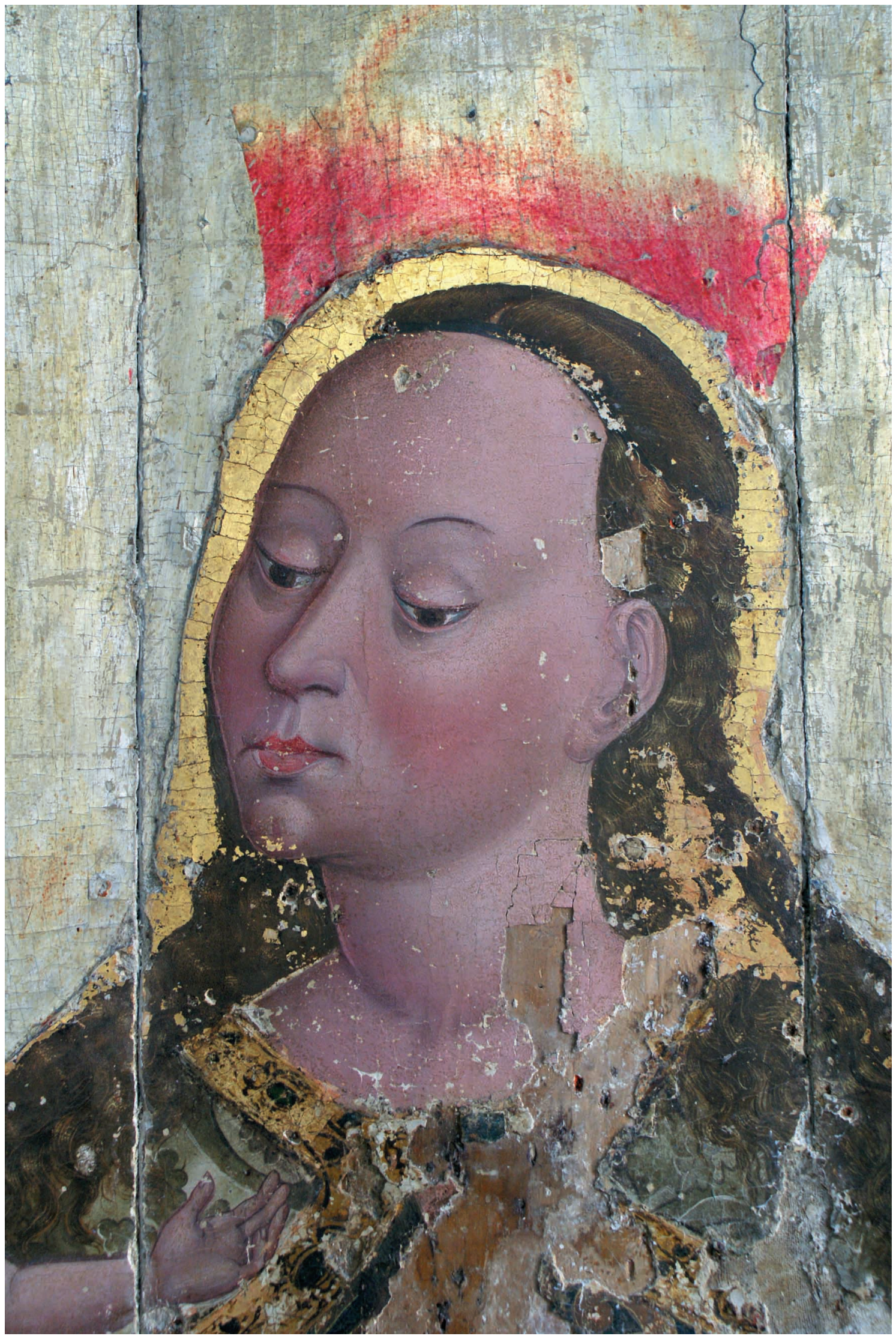

3. Franciszek z Węgier, Madonna z Alwerni-zbliżenie na twarz Marii, tempera na desce, przed 1491, klasztor oo. Bernardynów w Alwerni. Fot. B. Zarębski 
wraz z Janem Kapistranem, wykształconego na terenie Włoch w środowisku neapolitańskim, ale zaznajomionego również z dziełami sztuki austriacko-czeskiej. Dziełem obu malarzy jest, zdaniem badaczek, Pietà z Tubądzina, datowana przez nie na lata 1453$1454^{17}$. Od czasu opublikowania artykułu Michałowskiej i Pezzi-Ascani Franciszek z Węgier był jedynie wzmiankowany w syntetycznych opracowaniach, m.in. u Jerzego Gadomskiego $^{18}$, w zbiorowej pracy Gotyckie malarstwo ścienne w Polsce ${ }^{19}$, u Andrzeja Efrema Obruśnika ${ }^{20}$ czy Jana Samka ${ }^{21}$.

Informacje o omawianym dziele pojawiają się w dwóch grupach archiwaliów, starszej dotyczącej klasztoru Bernardynów w Krakowie i nowszej poświęconej klasztorowi w Alwerni. W grupie pierwszej istotny jest katalog zmarłych bernardynów z ówczesnej prowincji polskiej autorstwa Innocentego z Kościan i Józefa z Pońca spisany w $1531 \mathrm{r}^{22}$ oraz podobny dokument, dotyczący jednak już tylko klasztoru krakowskiego, spisany w $1607 \mathrm{r}$. przez Hieronima Przybińskiego ${ }^{23}$. W obu tych źródłach między 1487 a 1491 r. wpisano nekrolog brata Franciszka, malarza, który wymalował wszystkie przedstawienia do ołtarza głównego ${ }^{24}$. W przypadku pierwszego dokumentu mamy również informację o tym, że obrazy te znajdują się obecnie w krużgankach ${ }^{25}$. Z obydwu katalogów dowiadujemy się ponadto, że brat Franciszek przed przyjęciem święceń był żonaty, jednak w pewnym momencie przywdział bernardyński habit, jego żona zaś wstąpiła do klasztoru św. Agnieszki w Krakowie. Podobnie postapił ich syn Cherubin, który także przyjął święcenia zakonne u bernardynów ${ }^{26}$. Oba te źródła znajdują również potwierdzenie w powstałej w latach 30. XVI w. kronice Jana z Komorowa. Choć autor tego dokumentu nie mówił bezpośrednio o interesującym nas artyście, opisywał jednak śmierć jego syna, brata Cherubina, i przy okazji wspomniał o ojcu tegoż zakonnika. Istotne wydaje się to, że Komorowski poruszył w swej kronice kwestię pochodzenia Franciszka, określając go jako malarza z Węgier ${ }^{27}$.

\footnotetext{
${ }^{17}$ Maria OTTO-MICHAŁOWSKA, Maria Luisa PEZZI-ASCANI, „Motywy włoskie w malarstwie małopolskim XV wieku”, Biuletyn Historii Sztuki, XXXVII:1975, nr 2, s. 126-134.

18 Jerzy GADOMSKI, Gotyckie malarstwo tablicowe Małopolski 1420-1470, Warszawa 1981, s. 30, 62, 65; id., Gotyckie malarstwo tablicowe Małopolski 1460-1500, Warszawa 1988, s. 20, 85-86, 95. Autor powtórzył za Gąsiorowskim błędne informacje na temat autorstwa trzech wymienionych wyżej obrazów.

${ }^{19}$ Marian KORNECKI, Helena MAŁKIEWICZÓWNA, „Małopolska”, [w:] Gotyckie malarstwo ścienne w Polsce, red. Alicja KARŁOWSKA-KAMZOWA, Poznań 1984, s. 34.

${ }^{20}$ Andrzej Efrem OBRUŚNIK, „Bernardyńscy malarze ksiąg choralnych w okresie gotyku”, [w:] Pięćset pięćdziesiąt lat obecności oo. Bernardynów w Polsce (1453-2003), red. Wiesław MURAWIEC, Damian MUSKUS, Kalwaria Zebrzydowska 2006, s. 568, 577.

${ }^{21}$ Jan SAMEK, „Sztuka i rzemiosło artystyczne oraz programy ikonograficzne u bernardynów na polskich przykładach", [w:] Pięćset pięćdziesiąt lat obecności oo. Bernardynów..., s. 606. Badacz wymienił tu Franciszka z Węgier w kontekście malarstwa miniaturowego.

${ }^{22}$ Dokument znany jest obecnie z dwóch kopii pochodzących z początku XVII w.: APBK, APW, W-37, k 443-487v; APBK, APW, W-20; zob. Hieronim Eugeniusz WYCZAWSKI, „Innocenty z Kościana”, [w:] Słownik polskich pisarzy franciszkańskich..., s. 179-180.

${ }^{23}$ APBK, AKK, I-b-20; zob. Hieronim Eugeniusz WYCZAWSKI, „Przybiński Hieronim”, [w:] Polski słownik biograficzny, t. 29, red. Emanuel ROSTWOROWSKI, Wrocław-Warszaw-Kraków-Gdańsk-Łódź 1986, s. 73.

${ }^{24}$ APBK, AKK, I-b-20, s. 2-3; APBK, APW, W-37, k 446; APBK, APW, W-20, s. 11.

${ }^{25}$ APBK, APW, W-37, k 446; APBK, APW, W-20, s. 11

${ }^{26}$ APBK, AKK, I-b-20, s. 2-3; APBK, APW, W-20, s. 11.

${ }^{27}$ Memoriale Ordinis Fratrum Minorum a Fr. Ioanne de Komorowo compilatum, wyd. Xawery LISZKE, Antoni LORKIEWICZ, [w:] Monumenta Poloniae historica, t. 5, Lwów 1888, s. 275; polski przekład: Jan z Komorowa, Kronika Zakonu Braci Mniejszych Obserwantów, tłum. Kazimierz Żuchowski, Kalwaria Zebrzydowska 2014, s. 269. Można zauważyć, że postać Franciszka z Węgier jest również dwukrotnie wymieniona w powstałym w krakowskim klasztorze
} 


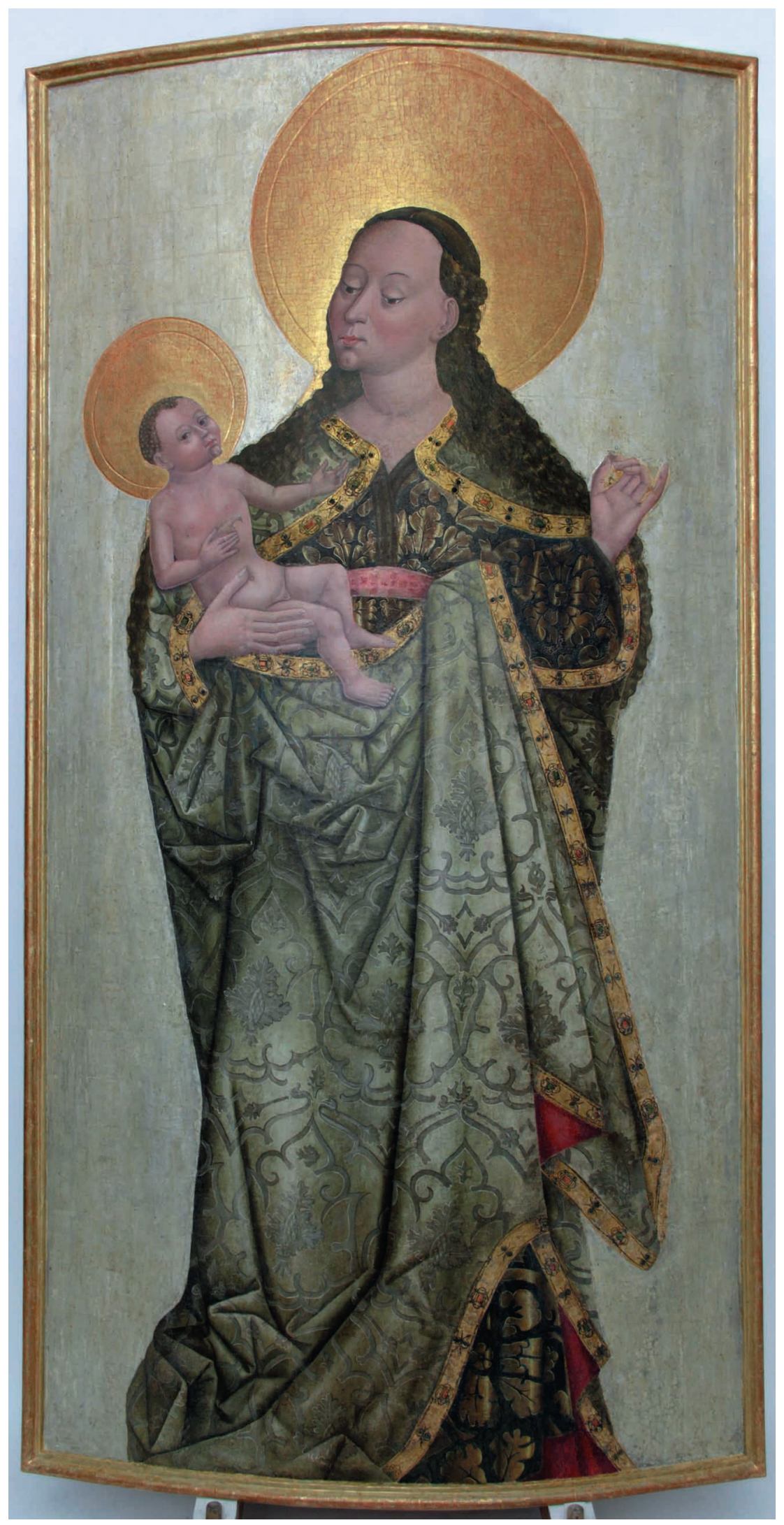

4. Franciszek z Wegier, Madonna z Alwerni - stan po konserwacji, tempera na desce, przed 1491, klasztor oo. Bernardynów w Alwerni. Fot. B. Zarębski 


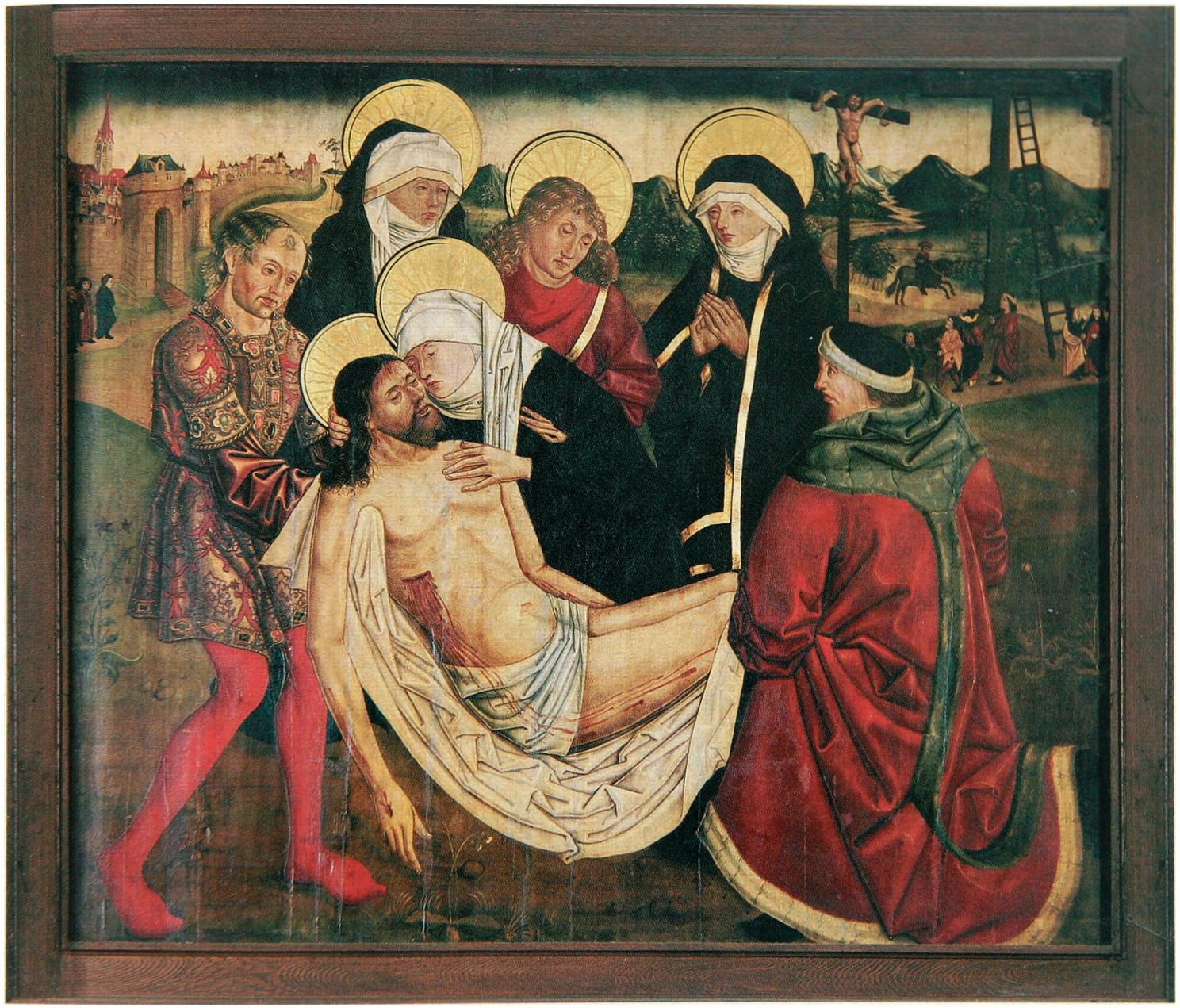

5. Opłakiwanie Chrystusa, tempera na desce, przed 1478, kwatera z dawnego ottarza głównego w kościele p.w. św. Marcina (ob. katedra) w Spiskiej Kapitule. Repr. wg: Gotika, Bratislava 2003, s. 387, il. 336

W przypadku archiwaliów dotyczących klasztoru w Alwerni wymienić trzeba przede wszystkim dwie kroniki konwentu. Pierwszą z nich zaczął spisywać w 1649 r. o. Daniel Zieliński $^{28}$, stworzenie drugiej zlecił w 1757 r. ówczesny gwardian o. Anioł Hlavsa ${ }^{29}$. W obu tych dokumentach pojawia się identycznie opisana historia, z której wynika, że omawiany obraz został sprowadzony do Alwerni z pierwszego polskiego konwentu Bernardynów, znajdującego się w Krakowie na Stradomiu. Tam też umieszczony był pierwotnie w ołtarzu głównym kościoła klasztornego, ale w momencie fundacji nowej nastawy z malowanym przedstawieniem Ukrzyżowania przeniesiono go do krużganków i umiesz-

dokumencie Miracula beati patris Simonis Lypnycensis jako świadek dwóch zeznań cudownie uzdrowionych osób, spisanych pomiędzy latami 1483 a 1487, chociaż źródło to nie określa Franciszka mianem malarza, można jednak przypuszczać, że chodzi tu właśnie o twórce przedstawień do głównego ołtarza; zob. Miracula collectore Nicolao Sokolmikio Ordinis Minorum, [w:] Acta Sanctorum Julii, t. 4, Pariis \& Romae 1868, s. 545, 555; APBK, Archiwalia Prowincji Ruskiej, tzw. Galicyjskiej i obecnej Polskiej, RGP-k-12, s. 179, 289).

${ }^{28}$ APBK, AKA, II-1. Wpisy w pierwszej kronice kończą się na 1755 r. Więcej o Danielu Zielińskim zob.: Kamil KANTAK, Bernardyni polscy, t. 2, Lwów 1933, s. 206; WYCZAWSKI, Alwernia..., s. 84-85; KNAPIK, op. cit., s. 51-54.

${ }^{29}$ APBK, AKA, II-2. Do drugiej kroniki, prowadzonej aż do lat 50. XX w., przepisano większość informacji, zawartych w starszej wersji. Więcej o Aniele Hlavsie zob.: KANTAK, Bernardyni polscy, t. 2, s. 206; WYCZAWSKI, Alwernia..., s. 73-77; KNAPIK, op. cit., s. 97-130. 


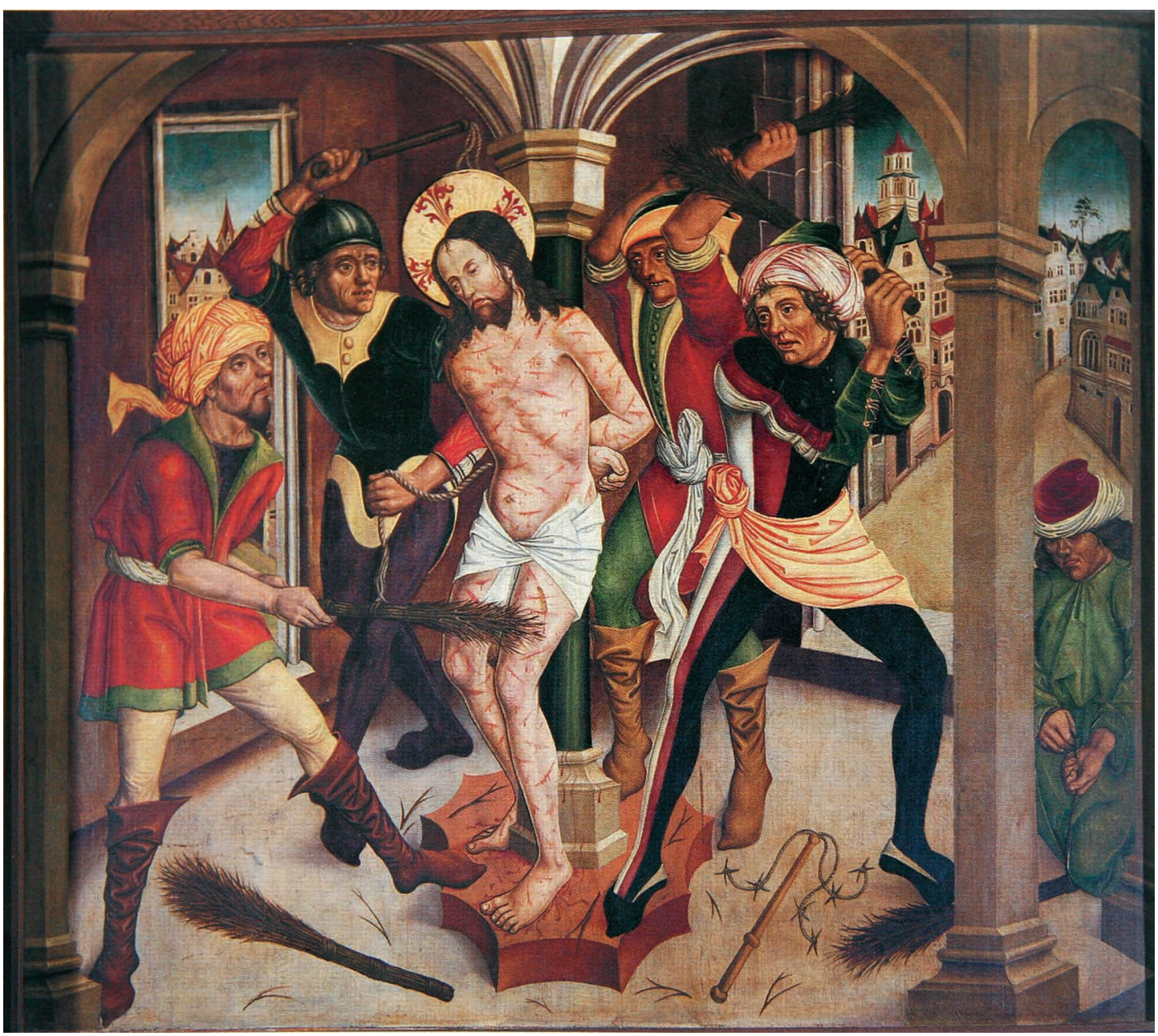

6. Biczowanie Chrystusa, tempera na desce, przed 1478, kwatera z dawnego ołtarza głównego kościoła p.w. św. Marcina (ob. katedra) w Spiskiej Kapitule. Repr. wg Gotika, Bratislava 2003,

$$
\text { s. 386, il. } 335
$$

czono w strukturze ołtarzowej obok refektarza. Po jakimś czasie został zastąpiony innym przedstawieniem maryjnym i ustawiony gdzieś z boku.

Porzuconym dziełem zainteresował się Piotr Poznański ${ }^{30}$ i na jego prośbę, prawdopodobnie w latach 1645-1646, zostało ono wysłane do alwernijskiego klasztoru, gdzie stanęło początkowo w ołtarzu w prowizorycznym drewnianym kościele ${ }^{31}$. Dowiadujemy się również, że omawiany obraz był wtedy szerszy i z jednej strony miał przedstawienie św. Franciszka, z drugiej św. Bernardyna, jednakże zbyt małe rozmiary nastawy zmusiły do rozdzielenia przedstawienia i dwóch świętych znalazło się na ruchomych skrzydłach, przymocowanych do tej struktury ${ }^{32}$. W roku 1660 najprawdopodobniej już samo przedstawienie

\footnotetext{
${ }^{30}$ Prawdziwe nazwisko Piotra Poznańskiego brzmiało Bieliński; zob. Hieronim Eugeniusz WYCZAWSKI, „Piotr z Poznania", [w:] Stownik polskich pisarzy franciszkańskich..., s. 377-380; KNAPIK, op. cit., s. 21.

${ }^{31}$ APBK, AKA, II-1, k. 7, APBK, AKA, II-2, k. 89.

${ }^{32}$ APBK, AKA, II-1, k. 7; APBK, AKA, II-2, k. 89. Budowa oraz ślady obróbki zachowanego podobrazia, pozwalają przypuszczać, że środkowa kwatera ołtarza głównego kościoła Bernardynów w Krakowie składała się z trzech oddzielnych podobrazi, połączonych wspólną ramą. Swoją formą mogła przypominać np. środkową kwaterę poliptyku z Dobczyc; zob. GADOMSKI, Gotyckie malarstwo tablicowe Małopolski 1460-1500, s. 166; id., Malarstwo gotyckie Małopolski 1500-1540, s. 78-79; id., „Mistrz Rodziny Marii - krakowski malarz pierwszej ćwierci XVI wieku”, Folia Historiae Artium, 28:1992, s. 79-80, 95-93.
} 


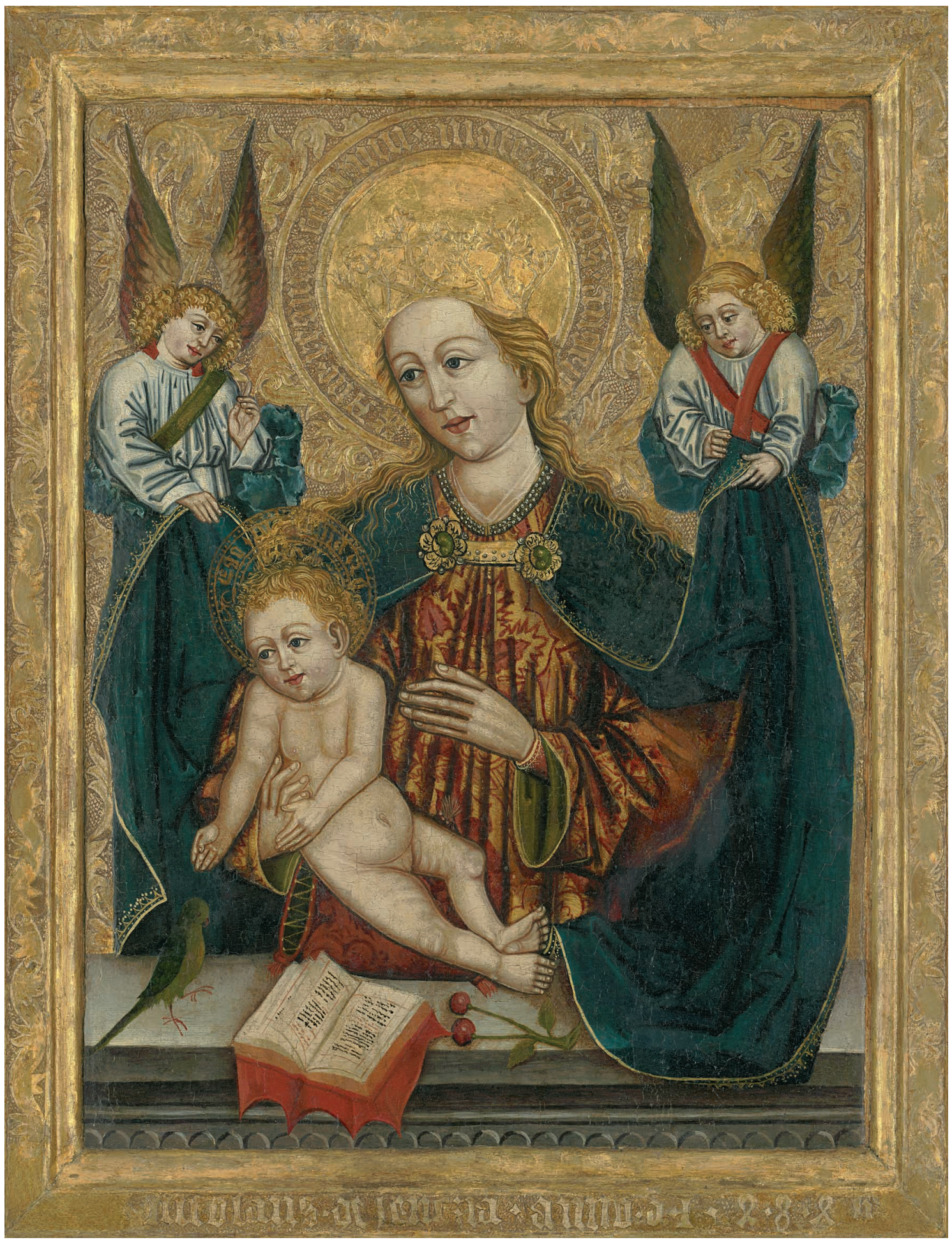

7. Mikołaj z Lewoczy, Madonna z Popradu, tempera na desce, 1484, Stowacka Galeria Narodowa w Bratystawie. Fot. Oddelenie digitálnych techológií, Slovenská národná galeria Bratislava 


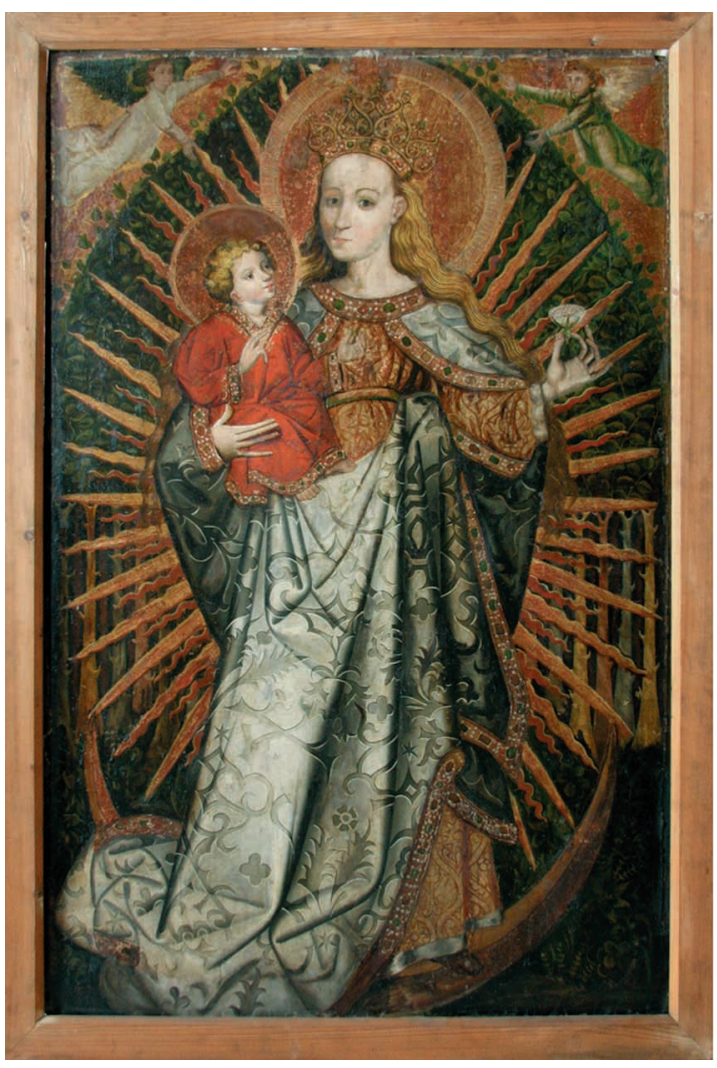

8. Madonna z Cerekwi, tempera na desce, ok. 1460, Muzeum Diecezjalne w Tarnowie.

Fot. ks. T. Bukowski

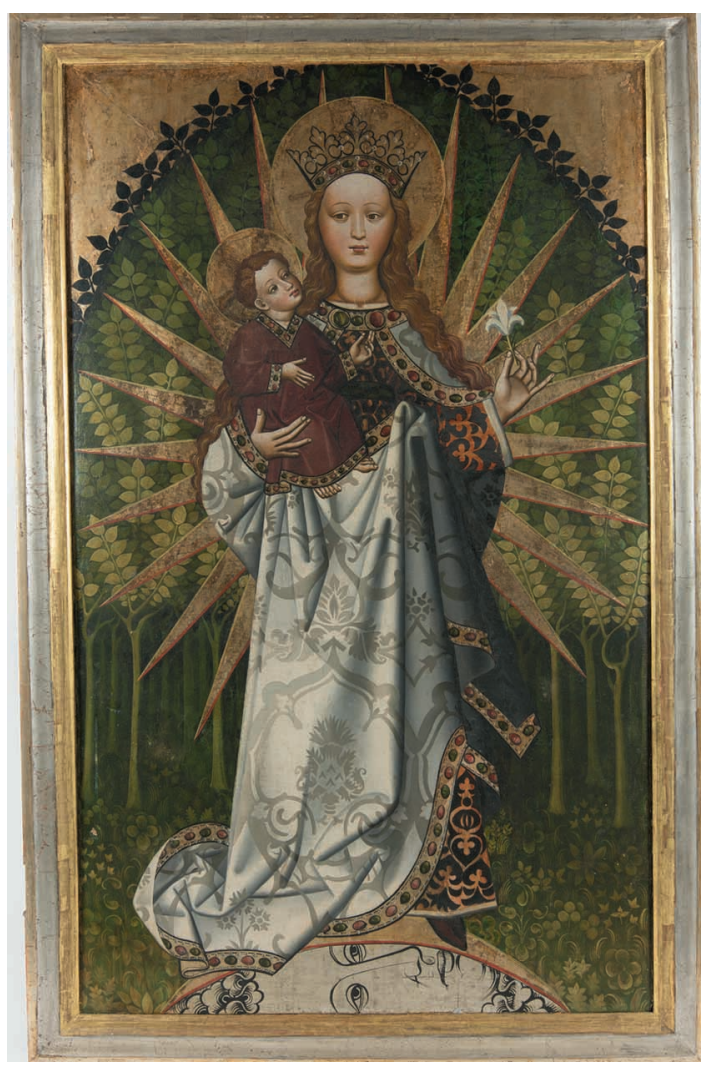

9. Madonna z Przydonicy, tempera na desce, ok. 1450-1460, kościót p.w. Matki Boskiej Różańcowej i św. Jana Kantego w Przydonicy. Fot. P. Gasior

Madonny przeniesiono do murowanego kościoła i ulokowano w ołtarzu w nawie ${ }^{33}$. W 1745 r. obraz trafił do ołtarza św. Bernardyna, znajdującego się w chórze zakonnym ${ }^{34}$. W 1952 r. ołtarz ów został zlikwidowany, zaś przedstawienie Madonny, przykryte już wtedy licznymi warstwami przemalowań, znalazło się najprawdopodobniej w klasztornych krużgankach ${ }^{35}$.

Z pierwotnych warstw dzieła zachowały się do dziś jedynie postaci Marii i Dzieciątka, z wyłączeniem ornamentu malowanego na lamówce płaszcza, który pochodzi przypuszczalnie z XVII w. ${ }^{36}$ (il. 1). Analizę tego przedstawienia należy przeprowadzić uwzględniając kontekst wynikający z archiwaliów. Jan z Komorowa wspominając, że autor obrazu z Alwerni miał pochodzić z Węgier, użył wyrażenia Francicseus, pictor de Ungaria ${ }^{37}$, co sugeruje, że postać ta uczyła się fachu malarskiego właśnie w tym kraju. Choć możliwe jest, że określenie to odnosiło się tylko do rodowodu jego przodków, na obce pochodzenie

\footnotetext{
${ }^{33}$ APBK, AKA, II-1, k. 4; APBK, AKA, II-2, k. 89.

${ }^{34}$ APBK, AKA, II-2, k. 89, 92.

${ }^{35}$ APBK, AKA, II-2, k. 89.

${ }^{36}$ Datowanie to wynika z układu poszczególnych warstw przemalowań, jakie znajdowały się na obrazie. Należy również zaznaczyć, że z pięciu desek, z których składa się obecnie podobrazie, tylko trzy środkowe są elementami oryginalnej struktury. ${ }^{37}$ Należy zaznaczyć, że w XV w. w skład Królestwa Węgier wchodziła praktycznie całość Kotliny Panońskiej, czyli poza terenami dzisiejszych Węgier także obszary Słowacji i Siedmiogrodu. Ponadto państwo to było połączone unią personalną z Królestwem Chorwacji; zob. János BAK, „Ungarn”, [w:] Lexikon des Mittelalters, t. 8, red. Norbert ANGERMANN et al., München 1997, s. 1226-1234.
} 


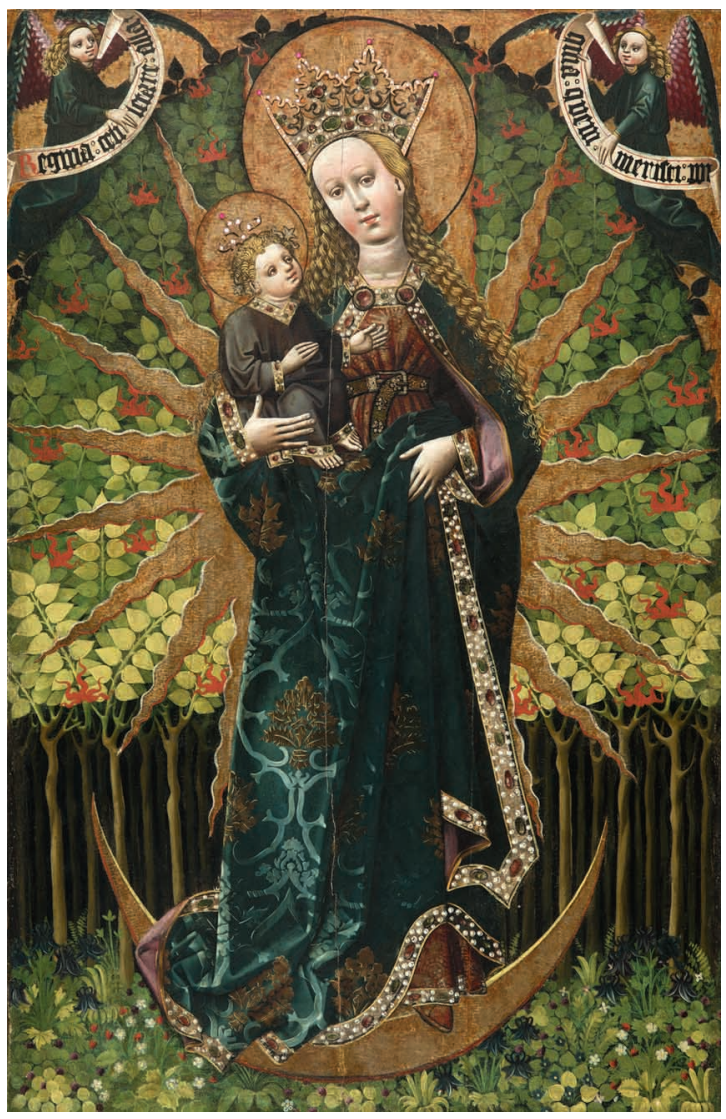

10. Madonna z Paczółtowic, tempera na desce, 1460-1465, kościót p.w. Nawiedzenia Najświętszej Marii Panny w Paczóltowicach. Fot. Pracownia Fotograficzna Muzeum Narodowego w Krakowie

malarza wskazują również inne elementy. Jest to m.in. sposób potraktowania formy malarskiej, prezentujący się dość nietypowo jak na region Małopolski, co objawia się chociażby w szczegółach fizjonomicznych, które miejscami wydają się w nienaturalny sposób pogłębione i podkreślone. Charakterystyczny jest tu zwłaszcza sposób malowania brody obu postaci, przybierającej kształt zbliżony do okręgu przedzielonego na środku kreską (i1. 2-3). Przeglądając dzieła z terenów Małopolski można zauważyć, że tak potraktowany szczegół anatomiczny występuje na nich jedynie sporadycznie. Znamienny jest również wstępny rysunek, który na obrazie z Alwerni zrealizowany został niezwykle subtelną i delikatną kreską, widoczną jedynie w niektórych ubytkach i na zdjęciu w podczerwie$\mathrm{ni}^{38}$. W Małopolsce malarze doby gotyku przy takich działaniach operowali zazwyczaj grubym i wyraźnym konturem oraz szrafowaniem, wykonanymi najczęściej pędzlem i czarną farbą ${ }^{39}$. Trzeba też zauważyć, że na omawianym dziele, zwłaszcza w partiach karnacji i odsłoniętych fragmentów ciała, warstwa malarska położona została wyjątkowo grubo, podczas gdy małopolskie obrazy tablicowe właśnie w partiach karnacji malowane były z reguły cieniej, a czasem wręcz laserunkowo ${ }^{40}$.

Cechy te wskazuja, że obrazu z Alwerni nie da się związać z malarstwem późnego gotyku na terenie Małopolski. Podążając za przesłankami archiwalnymi, da się zauważyć pewne zbieżności z pochodzącymi z tego czasu dziełami węgierskimi, szczególnie zaś ze spiskimi. Przykładem tego mogą być m.in. kwatery z dawnego ołtarza głównego w ko-

\footnotetext{
${ }^{38}$ Warto zaznaczyć, że na obrazie zachowały się również ślady użycia przepróchy, które widoczne są na krawędziach ornamentu z płaszcza Marii.

${ }^{39}$ GADOMSKI, Gotyckie malarstwo tablicowe Małopolski 1460-1500, s. 102.

${ }^{40}$ GADOMSKI, Gotyckie malarstwo tablicowa Małopolski 1420-1470, s. 70, 73; id., Gotyckie malarstwo tablicowe Małopolski 1460-1500, s. 104-105.
} 
11. Madonna z Kamienicy, tempera na desce, ok. 1460, Muzeum Ślaska Cieszyńskiego w Cieszynie. Fot. H. Wawreczka

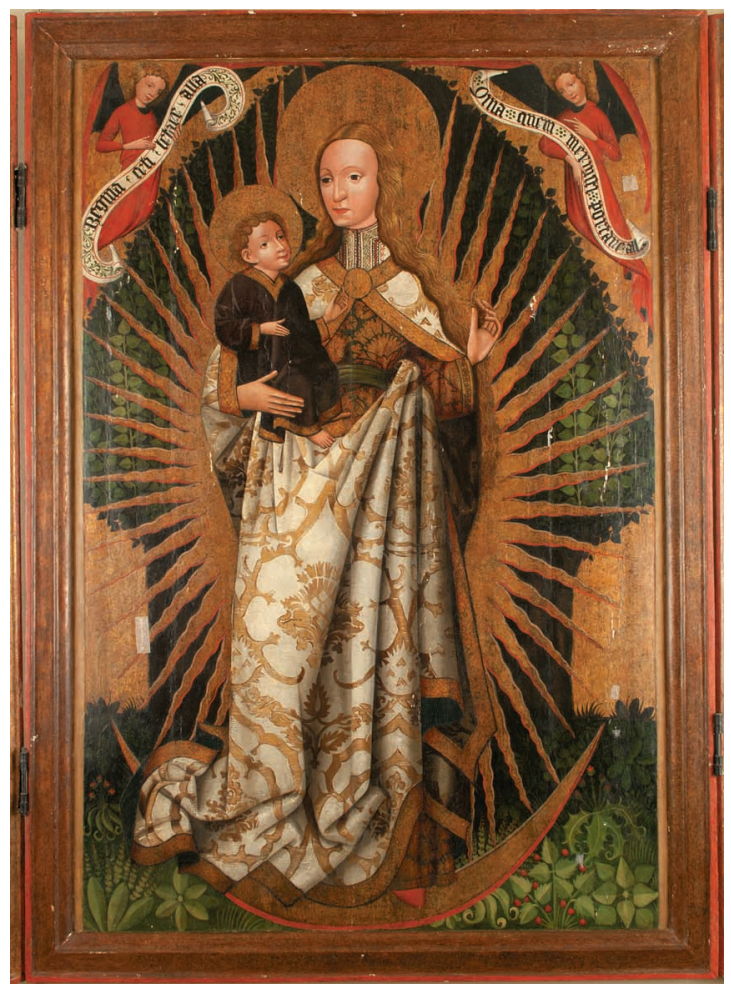

ściele św. Marcina w Spiskiej Kapitule, powstałe najprawdopodobniej przed 1478 r. $^{41}$ Pojawia się na nich, podobnie jak na obrazie z Alwerni, charakterystyczne pogłębienie i podkreślenie niektórych szczegółów fizjonomii, które dobrze widoczne jest m.in. w przypadku Józefa z Arymatei w scenie Opłakiwania (il. 5) i na twarzach oprawców w scenie Biczowania (il. 6). Podobne cechy pokazuje też m.in. Madonna z Popradu, dzieło wykonane prawdopodobnie przez Mikołaja z Lewoczy w roku 1484 (il. 7) ${ }^{42}$.

Oprócz argumentów przemawiających za węgierskim, tudzież spiskim pochodzeniem artysty, w omawianym dziele dostrzega się wyraźne powiązania z małopolską tradycją artystyczną, o czym świadczą wykorzystana kompozycja i ikonografia. Trzy formalnie najbliższe mu dzieła z terenów Małopolski to Madonny z Cerekwi (ok. 1460; il. 8) i Przydonicy (ok. 1450-1460; il. 9) ${ }^{43}$ oraz z Paczółtowic (1460-1465; il. 10) ${ }^{44}$. Do tej grupy można dodać jeszcze Madonnę z Kamienicy na Śląsku Cieszyńskim (ok. 1460; il. 11), wykazującą silne zbieżności z trzema z wymienionych wyżej obrazami i prawdopodobnie również powstałą w Małopolsce ${ }^{45}$. Owe cztery dzieła dają nam wyobrażenie o tym, jak

\footnotetext{
${ }^{41}$ János VÉGH, „Spišské maliarstvo poslednej tretiny 15. storočia”, [w:] Gotika, red. Dušan BURAN, Bratislava 2003, S. 382-386, 401-402; Jiří FAJT, "Medzi dvora a mestom. Maliarstwo na Spiši okolo roku 1500 a magnátska rodina Zápol'skich”, ibid., s. 399-410.

42 VÉGH, op. cit., s. 391.

${ }^{43}$ Tamara ŁOZIŃSKA, „Cerekiew”, [w:] Malarstwo gotyckie w Polsce, t. 2: Katalog zabytków, red. Adam LABUDA, Krystyna SECOMSKA, Warszawa 2004 s. 149 (Dzieje Sztuki Polskiej, t. 2, cz. 3); Witold RĄCZKOWSKI, „Przydonica", [w:] ibid., s. 243-244.

${ }^{44}$ GADOMSKI, Gotyckie malarstwo tablicowa Małopolski 1420-1470, s. 127.

45 Witold RĄCZKOWSKI, „Kamienica”, [w:] Malarstwo gotyckie w Polsce, s. 184-185. Badacze wielokrotnie już podkreślali silne związki obrazu ze znajdującej się na Śląsku Cieszyńskim Kamienicy z regionem małopolskim; zob. Tadeusz DOBROWOLSKI, Sztuka województwa Ślaskiego, Katowice 1933, s. 60-61; id., Rzeźba i malarstwo gotyckie w województwie ślaskim, Katowice 1937, s. 64-65; id., Sztuka na Ślasku, Katowice-Wrocław 1948, s. 165; Józef WZOREK, „Madonna Apokaliptyczna z Cerekwi w Tarnowskim Muzeum Diecezjalnym”, Roczniki Humanistyczne, 13:1965, z. 3, s. 134, 144; Zbigniew STRZAŁKOWSKI, „Malarstwo tablicowe w szkole sądeckiej”, Rocznik Sądecki, 1967, t. 8,
} 
pierwotnie mógł wyglądać omawiany obraz, jak również pozwalają stwierdzić, że prezentował typ ikonograficzny, określany mianem Madonny Apokaliptycznej ${ }^{46}$.

Można więc z dużym prawdopodobieństwem uznać, że wzmiankowany w źródłach malarz Franciszek, wykształcił się na terenie Królestwa Węgier, zapewne w regionie spiskim. Przybył do Małopolski nie wcześniej niż z końcem latach 70. XV w., musiał bowiem mieć czas, by zaznajomić się z rodzimą sztuką z początków ostatniej ćwierci tego stulecia. W krakowskim klasztorze namalował przedstawienia do ołtarza głównego, w tym omawiane dzieło. Tworząc je zaadoptował popularny na ziemiach małopolskich schemat ikonograficzny, posługując się jednak poznanym już wcześniej warsztatem. W kwestii datowania omawianego obrazu, jak i całego ołtarza, jako terminus ante quem należy przyjąć rok 1491, czyli najpóźniejszą możliwą datę śmieci Franciszka z Węgier. Biorąc pod uwagę domniemany czas przybycia malarza do Małopolski, za moment powstania ołtarza najsłuszniej uznać lata 80. XV w.

s. 389; GADOMSKI, Gotyckie malarstwo tablicowe Małopolski 1460-1500, s. 43; Andrzej M. OLSZEWSKI, „Mulier Amica Sole w sztuce gotyku w Polsce”, Nasza Przeszłość, 82:1994, s. 47.

${ }^{46}$ Nazewnictwo nie jest w tym wypadku sprecyzowane. Dzieła prezentujące ów temat określa się również mianem Assumpty lub Assunty bądź też Assumpty Apokaliptycznej (od łacińskiego Assumptio Mariae); zob. Josef CIBULKA, „Korunovaná Assumpta na půlmeíci. Příspevek k české ikonografii XIV. - XVI. stoleti’”, [w:] Sborní k sedemdesátým narozeninám Karla B. Mádla, red. Jan ŠTENC, Praha 1929, s. 80-127; Adam BOCHNAK, „Z dziejów malarstwa gotyckiego na Podkarpaciu”, Prace Komisji Historii Sztuki, 1934-1935, t. 6, s. 8-22; Andrzej GRZYBKOWSKI, „Warianty ikonograficzne Assunty z kobiecą maską lunarną", [w:] Sztuka i ideologia XV wieku. Materiały Sympozjum Komitetu o Sztuce Polskiej Akademii Nauk. Warszawa 1-4 grudnia, red. Piotr SKUBISZEWSKI, Warszawa 1978, s. 441-459; OLSZEWSKI, „Mulier amica sole...”, s. 35-94. Zob. też: Michał WALICKI, „Po wystawie polskiej sztuki gotyckiej w Instytucie Propagandy Sztuki”, Nike, 1937, t. 1, s. 58-59; WZOREK, op. cit., s. 117-145; STRZAŁKOWSKI, op. cit., s. 378-379, 388-389; Ewa POLAK-TRAJDOS, „Twórczość Mistrza Maciejowickiego na tle malarstwa rejonu sądeckiego XV wieku", Rocznik Historii Sztuki, 1973, t. 9, s. 98-118; Andrzej M. OLSZEWSKI, Pierwowzory graficzne późnogotyckiej sztuki małopolskiej, Wrocław-Warszawa-Kraków-Gdańsk 1975, s. 28-30; GADOMSKI, Gotyckie malarstwo tablicowe Małopolski 1420-1470, s. 51-52, 117-119. 


\section{Late Gothic Apocalyptic Madonna from the High Altar of the Bernardine Church in Kraków: Work of the Painter Francis of Hungary}

The recently discovered Late Gothic panel painting featuring the representation of the Apocalyptic Madonna, currently in the Alwernia Bernardine Church, is discussed. Based on archival written records, the Author connects the work with the high altar of the Bernardine Church in Kraków, and attributes it to the Bernardine painter Francis of Hungary who died in 1487-91.

The first section of the article is dedicated to presenting the state of investigation into the painting itself and its artist, to continue in the subsequent one to the reconstruction of the work's history on the grounds of archival records. In the last part, the analysis is conducted demonstrating lack of any formal bonds between the Lesser Poland painting of Late Gothic and the Alwernia work; finally, the
Author juxtaposes the analysed work with the panels of the former high alter of St Martin's Church in the Spisz Chapter and the painting of Madonna from Poprad. This leads to the conclusion that the author of the Alwernia Madonna, just as his nickname points to, came from the territory of the Kingdom of Hungary, most likely from around Spisz. Having reached Lesser Poland most likely in the late 1470s at the earliest, he executed the high altar for the Kraków Bernardine Church in the 1480s. Apart from the arguments pointing to the foreign descent of the artist, the Author also emphasizes the strong bond of the discussed painting with the Lesser Poland artistic tradition, this revealed when the painting is compared with the Madonnas from Cerekwia, Przydonica, Paczółtów, and Kamienica.

Translated by Magdalena Iwińska 
